\title{
AKTYWIZACJA SPOLECZNA WSPÓLNOT TERYTORIALNYCH W POLSCE Z PERSPEKTYWY ĆWIERĆWIECZA SAMORZĄDU TERYTORIALNEGO
}

\section{WSTĘP: OBYWATELSKIE NADZIEJE ZWIĄZANE Z ODRODZENIEM SAMORZĄDU TERYTORIALNEGO}

Odrodzenie samorządu terytorialnego w 1990 r. stanowiło zasadniczą zmianę ustrojowa. Na mocy ustawy z 8 marca 1990 r. (Dz. U. 1990, Nr 16, poz. 95) gminy uzyskały podmiotowość prawna, stały się właścicielem majątku i przejęły obowiązki dostarczania usług publicznych, wcześniej w znacznej mierze organizowanych przez zakłady pracy ${ }^{1}$. Władze gmin wybrane w wolnych wyborach, które odbyły się 27 maja 1990 r., stały się tym samym demokratycznym reprezentantem lokalnych społeczności. Oczekiwania z okresu tworzenia samorządu dotyczyły trzech obszarów: a) aktywizacji społeczności lokalnych (uczestnictwa w sprawowania władzy i w przedsięwzięciach rozwojowych); b) podmiotowości (brania odpowiedzialności przez mieszkańców za rozwój wspólnoty); c) odbudowy społeczeństwa obywatelskiego (aktywności publicznej mieszkańców) ${ }^{2}$. Oczekiwania te bazowały na takich ideach, jak: podmiotowość, subsydiarność czy decentralizacja, oraz wzorach zaczerpniętych (częściowo w sposób wyidealizowany) z zachodnich społeczeństw demokratycznych. Reformatorzy przyjmowali ogólne, choć bazujące na istniejących koncepcjach teoretycznych i badaniach, przekonanie, że istnieja zasoby energii społecznej i aktywności, które były zablokowane w czasach komunistycz-

1 J. Regulski, Samorzqdna Polska, Warszawa 2005, s. 20.

${ }^{2}$ Pisali o tym, m.in.: A. Piekara, Administracja, samorzad terytorialny, aktywność społeczna i rozwój, Warszawa 2005; idem, Wartości, istota, uwarunkowania i funkcje społeczne samorzadu terytorialnego a rozwój lokalny, w: A. Piekara, Z. Niewiadomski (red.), Samorzad terytorialny i rozwój lokalny, Warszawa 1996; A. Piekara, Samorzad terytorialny a kreatywność społeczna i rozwój lokalny. Przyczynek do problematyki decentralizacji demokracji lokalnej oraz ich funkcji $i$ dysfunkcji, w: P. Buczkowski, R. Sowiński (red.), Samorzad terytorialny droga do demokracji, Poznań 1994; B. Jałowiecki, Rozwój lokalny, Warszawa 1989; P. Buczkowski, Samorzad lokalny $i$ budowa społeczeństwa obywatelskiego w Polsce do 1990 r., w: idem (red.), Odrodzenie samorzadu terytorialnego, Poznań 1994. 
nych. Uznawano, że mogą one być uwolnione dzięki reformie samorządowej i przyniesie to dobroczynne skutki ekonomiczne i społeczne ${ }^{3}$.

Należy zauważyć, że pięćdziesiąt lat przerwy w funkcjonowaniu demokracji lokalnej oznacza w socjologicznym sensie dwa pokolenia - niemożliwe zatem było odtworzenie samorządu przez bezpośrednie, także biograficzne, nawiązanie do stanu sprzed II wojny światowej. W społecznym sensie samorząd terytorialny został niejako stworzony na nowo ${ }^{4}$.

Część oczekiwań sprawdziła się - wybory samorządowe i kolejne lata przyniosły falę aktywności zogniskowaną wokół komitetów obywatelskich ${ }^{5}$, a dla większości radnych początku lat dziewięćdziesiątych XX w. była to pierwsza funkcja publiczna i z entuzjazmem włączyli się oni w działalność samorządowa. Jednak wraz z trudnościami z odbudową podmiotowej roli społeczności lokalnych, samorządy lokalne napotkały przeszkody typowe dla społeczeństw demokratycznych (pasywność i apatia wielu obywateli, wpływy grup interesów zagrażające interesowi wspólnemu, aktywność przybierająca jedynie postać protestu wobec decyzji władz itd.). Odradzające się media koncentrowały się na aferach, dając negatywny obraz samorządu, co prowadziło do erozji odbudowywanego zaufania ${ }^{6}$. Frustracja i zły odbiór przez mieszkańców działań nowo wybranych radnych prowadziły do tego, że wkrótce po wyborach $80 \%$ z nich deklarowało, że nie ma zamiaru ponownie kandydować . Obraz rozwoju samorządności w Polsce nie jest jednoznaczny. Celem niniejszego artykułu jest zarysowanie odpowiedzi na pytanie, w jakiej mierze oczekiwania związane z rewitalizacją społeczności lokalnych (oraz regionalnych) poprzez odrodzenie samorządu terytorialnego zostały spełnione - w jakim stopniu zatem realizację znalazła idea pomocniczości ${ }^{8}$. Kwestia ta jest analizowana na przykładzie kilku obszarów życia społecznego: a) aktywności tzw. trzeciego sektora i współpracy organizacji pozarządowych z jednostkami samorządu terytorialnego (pomocniczość pozioma); b) stosowania procedur i technik partycypacji (właczania obywateli do procesu podejmowaniu decyzji publicznych); c) działania jednostek pomocniczych (rad osiedli i sołectw - pomocniczość pionowa); d) aktywności obywatelskiej w postaci ruchów i inicjatyw społecznych (zwłaszcza tzw. ruchów miejskich); e) regionalizmu.

${ }^{3}$ J. Wiench, Samorzadność a postawy spoteczne, Warszawa 1990.

${ }^{4} \mathrm{O}$ niemożności nawiązywania do tradycji w odniesieniu do reform administracji publicznej pisał H. Izdebski, Wspótczesne modele administracji publicznej, Warszawa 1993.

${ }^{5}$ T. Borkowski, A. Bukowski (red.), Komitety obywatelskie: powstanie, rozwój, upadek, Kraków 1993.

${ }^{6}$ P. Buczkowski, Społeczna recepcja reformy samorzadowej, „Samorząd Terytorialny” 2, 1992 , nr 11.

${ }^{7}$ E. Łojko, Socjologiczne problemy samorzadności lokalnej, w: A. Piekara, Z. Niewiadomski (red.), op. cit.

${ }^{8}$ Jako że reforma wprowadzająca powiaty miała miejsce później i zasługuje na osobną analizę, w przedstawionym opracowaniu poziom powiatów nie jest szczegółowo omawiany. 


\section{CZY SEKTOR POZARZAॄDOWY JEST PARTNEREM JEDNOSTEK SAMORZĄDU TERYTORIALNEGO?}

Jak już wskazano, po 1989 r. idea polskiej samorządności zakładała odrodzenie i partnerską współpracę dwóch uzupełniających się sektorów: samorządu terytorialnego i aktywności obywatelskiej. Żywiołowy rozwój organizacji obywatelskich, a także późniejsze wprowadzenie obowiązku współpracy z nimi jednostek samorządu terytorialnego, podobnie jak wymagania Unii Europejskiej, wydawały się tworzyć warunki do sytuacji partnerskiej współpracy sektora samorządowego z pozarządowym.

\section{Organizacje pozarządowe - dynamika rozwoju po $1989 \mathrm{r}$.}

Samorządy lokalne i organizacje pozarządowe są niemal równolatkami pole dla rozwoju zarówno sektora samorządowego, jak i pozarządowego otworzyło się po 1989 r. Wcześniej, w okresie komunistycznym po likwidacji organizacji, stowarzyszeń i innych form aktywności społecznej, skanalizowano ją w niewielu organizacjach (Polski Czerwony Krzyż, Związek Harcerstwa Polskiego, Towarzystwo Przyjaciół Dzieci itp.). „Przerwany etos”10 odrodził się w oddolnej postaci jako „społeczeństwo alternatywne” lat osiemdziesiątych, jednakże 90\% obecnie funkcjonujących organizacji powstało po 1989 r., kiedy ponownie było to legalne i dopuszczalne ${ }^{11}$, a naturalna przestrzenia ich działania były społeczności lokalne (dla 60\% organizacji przestrzenny zakres działalności jest ograniczony do gminy lub powiatu $\left.{ }^{12}\right)$. Liczba organizacji pozarządowych nadal rośnie. O ile w 1997 r. w Polsce funkcjonowało 27,4 tys. organizacji pozarządowych, o tyle w 2012 było ich już trzykrotnie więcej (83,5 tys., w tym 8 tys. organizacji pożytku publicznego $\left.{ }^{13}\right)$.

\section{Trzeci sektor a samorządy - uwarunkowania relacji}

Wzrost liczby organizacji można uznać za jeden z przejawów rozwoju samoorganizacji społecznej, lecz równoległym, ważnym czynnikiem były zmiany otoczenia prawnego i instytucjonalnego. Wprowadzanie nowych form dialogu społecznego w administracji ${ }^{14}$ stworzyło nowe warunki dla trzeciego sektora. Podstawowym aktem prawnym, regulującym współpracę organizacji pozarządowych z innymi podmiotami (w tym - z samorządem) oraz sytuację wolonta-

${ }_{9}$ M. Rymsza, Jaka Polska samorzadna? Jakie społeczeństwo obywatelskie? „Trzeci Sektor” 2014, nr 32, s. 8.

${ }^{10}$ E. Leś, Zarys historii dobroczynności i filantropii w Polsce, Warszawa 2001, s. 99.

${ }^{11}$ GHK, 2010, Study on Volunteering in the European Union. Country Report Poland, http:// ec.europa.eu/citizenship/pdf/national_report_pl_en.pdf, s. 1 [dostęp: 12.02.2015].

12 GUS, Wstepne wyniki badania społecznej i ekonomicznej kondycji organizacji trzeciego sektora $w 2012$ r., Warszawa 2014, s. 6.

${ }^{13}$ Ibidem.

${ }^{14}$ Szerzej: m.in. P. Gliński, Style dziatań organizacji pozarzadowych w Polsce: grupy interesu czy pożytku publicznego?, Warszawa 2006. 
riuszy, jest ustawa z 24 kwietnia 2003 r. o działalności pożytku publicznego i wolontariacie (znowelizowana w $2010 \mathrm{r} .{ }^{15}$ ), która przewiduje kilka form współpracy administracji publicznej z organizacjami pozarządowymi:

- zlecanie realizacji zadań publicznych;

- wzajemne informowanie się o planowanych kierunkach działalności i współdziałania;

- konsultowanie (odpowiednio do zakresu działania podmiotu) projektów aktów normatywnych;

- tworzenie wspólnych zespołów o charakterze doradczym i inicjatywnym ${ }^{16}$.

Formy te w przywołanej ustawie z 2003 r. miały charakter fakultatywny i były słabo wykorzystywane. Badania z 2004 i 2007 r. zrealizowane przez Instytut Spraw Publicznych pokazały, że zlecanie zadań było stosunkowo rzadkie, małe organizacje były marginalizowane, a realizacja obowiązku uchwalania przez jednostki samorządu terytorialnego (jst) rocznych programów współpracy z organizacjami pozarządowymi była rozczarowująca ${ }^{17}$. Nowelizacja ustawy zmieniła wskazane fakultatywne formy współpracy na obowiązkowe, doprecyzowano tryb konsultowania aktów normatywnych, ujednolicono tryb zlecania zdań z zakresu pomocy społecznej i usług rynku pracy, określono dokładnie sposób uchwalania planów współpracy i wprowadzono nowe formy współpracy, np. instytucje inicjatywy lokalnej (inicjatywy z udziałem ludności), w których samorząd dofinansowuje przedsięwzięcia (głównie infrastrukturalne), częściowo finansowane przez samych obywateli.

Mimo tych zmian prawa efektywna współpraca samorządów z organizacjami pozarządowymi napotyka przeszkody - należą do nich ${ }^{18}$ :

- zła sytuacja finansowa i trudności w utrzymaniu ciagłości finansowania działań (efektem jest „akcyjność”, niewielka skala działań i niska ich jakość);

- oparcie działań na niesystematycznej aktywności społeczników i wolontariuszy (przez co organizacje są dla partnerów samorządowych mało przewidywalne);

- dominacja „liderskiego modelu organizacji”19 (prowadzi to do oparcia współpracy na osobistych i nieformalnych relacjach lidera organizacji z przedstawicielem władz);

- słabe zaplecze infrastrukturalne i zarządcze organizacji pozarządowych.

Badania ujawniają też rozproszenie i konkurencyjność organizacji, co utrudnia wypracowanie trwałych zasad współpracy z jst ${ }^{20}$. Chociaż w 2011 r. aż 83\%

15 Dz. U. 2003, Nr 96, poz. 873 ze zm.

${ }^{16}$ A. Krajewska, Formy wspótpracy międzysektorowej po nowelizacji Ustawy o działalności pożytku publicznego $i$ o wolontariacie - perspektywy dla organizacji pozarzqdowych, „Trzeci Sektor" 2010/2011, nr specjalny, s. 66.

17 Ibidem.

${ }^{18}$ K. Górniak, Uwarunkowania wspótpracy międzysektorowej - co wynika z badań?, „Trzeci Sektor" 2010/2011, nr specjalny; P. Nosal, Organizacje pozarzqdowe $w$ relacjach z jednostkami samorzadu terytorialnego na przyktadzie województwa wielkopolskiego, „Trzeci Sektor” 2014, nr 32, s. 114 .

19 Por. P. Gliński, op. cit., s. 57-66.

${ }^{20}$ K. Górniak, op. cit. 
organizacji pozarządowych współpracowało z sektorem publicznym, to jednak zwykle współpraca ta miała charakter nieregularny i ukierunkowana była na pozyskanie środków finansowych ${ }^{21}$.

W efekcie można stwierdzić, że dominuje paternalistyczny charakter relacji samorządów i organizacji pozarządowych: urzędnicy „wpisuja się automatycznie w rolę edukatora-wychowawcy organizacji pozarządowych" ${ }^{22}$, spodziewaja się, że organizacje będą szanować dominująca pozycję zadań urzędniczych. Tymczasem organizacje oczekują współdziałania, zachowania raczej ducha prawa niż jego litery i faktycznego partnerskiego traktowania. Niewatpliwie pozytywną częścia tego obrazu jest funkcjonowanie wielu organizacji, które są sprawne, stabilne organizacyjnie i odnosza sukcesy w walce o zewnętrzne finansowanie ich działań ${ }^{23}$. Nie przekłada się to jednak na sukcesy w stawaniu się faktycznym dostarczycielem usług społecznych ${ }^{24}$.

Podsumowując, należy zauważyć, że choć w zakresie ram prawnych i oczekiwań zakłada się partnerstwo sektora pozarządowego i jst, to w praktyce widoczna jest nierówność - sektor pozarządowy w większości okazuje się zbyt słaby i niestabilny, aby liczyć na partnerskie traktowanie przez urzędników administracji lokalnej. Przez minione 25 lat samorządy okrzepły i dorosły, stając się - przynajmniej z punktu widzenia sfery aktywności obywatelskiej - raczej administracją niż sferą samorządności społeczności lokalnej. Społecznicy i aktywiści z pierwszych wyborów samorządowych ustapili pola menadżerom i politykom. Tymczasem sektor organizacji pozarządowych pozostał w dużej mierze rozproszony i efemeryczny. Wydaje się, że trwale pozostanie w roli młodszego brata, z którym starszy brat (jst) wprawdzie współpracuje, ale któremu nie zamierza oddawać pola. W pewnym sensie oznacza to porażkę obecnego od 1989 r. założenia, że odrodzona samorządność stanie stabilnie na dwóch filarach: struktur samorządu terytorialnego oraz oddolnej działalności obywatelskiej.

\section{CZY BUDŻET OBYWATELSKI I DZIALANIA PROPARTYCYPACYJNE TO REAKCJA NA SŁABOŚCI SAMORZĄDU TERYTORIALNEGO?}

W ciagu 25 lat funkcjonowania samorządu terytorialnego wzrosło wykorzystywanie mechanizmów partycypacyjnych - właczania obywateli w procesy decyzyjne, realizowane przez władze publiczne. Ocena tych mechanizmów

${ }^{21}$ GUS, Kapitał społeczny na poziomie mezo - wspótpraca organizacji trzeciego sektora, Warszawa 2013, s. 6.

${ }^{22}$ K. Górniak, op. cit., s. 30.

${ }^{23}$ E. Ciżewska, Polskie społeczeństwo obywatelskie. Jakie jest dziś $i$ co je czeka w przyszłości (sonda redakcyjna), „Trzeci Sektor” 2014, nr 32, s. 67. Jednocześnie specyficznym problemem polskich organizacji jest „grantoza”, por. A. Łęga, Polskie spoteczeństwo obywatelskie. Jakie jest dziś i co je czeka w przyszłości (sonda redakcyjna), „Trzeci Sektor” 2014, nr 32, s. 77.

${ }_{24}$ Jak zauważa E. Leś - organizacje nie są partnerem państwa, skoro tylko $2 \%$ z nich uzyskuje zamówienie publiczne w przetargu - eadem, Polskie społeczeństwo obywatelskie. Jakie jest dziś i co je czeka w przyszłości (sonda redakcyjna), ,Trzeci Sektor” 2014, nr 32, s. 74. 
wymaga pokazania ich genezy, istniejących regulacji prawnych oraz analizy zjawiska mechanizmów partycypacyjnych ze szczególnym uwzględnieniem budżetów obywatelskich (BO).

\section{Demokracja bezpośrednia}

Angażowanie obywateli w proces podejmowania decyzji istotnych dla danej społeczności stanowiło jedno z haseł reformy samorządowej w 1990 r. i po okresie, w którym możliwość udziału w demokratycznych wyborach wydawała się wystarczająca formą udziału obywateli w sprawowaniu władzy, rozwinęły się niewyborcze formy partycypacji. Początkowo była to głównie współpraca z organizacjami pozarządowymi. Wraz z upływem czasu w urzędach gmin powstały oddziały dialogu społecznego, które konsultacje społeczne traktowały szeroko, jako partycypację, a nie jedynie jako jeden ze szczebli drabiny partycypacyjnej ${ }^{25}$. Od $2011 \mathrm{r}$. kolejne miasta zaczęły cyklicznie realizować $\mathrm{BO}^{26}$ bądź konsultować projekty przestrzenno-infrastrukturalne ${ }^{27}$.

Wskazuje się, że partycypacja w procesie decyzyjnym przyczynia się do $\mathrm{do}^{28}$ : demokratyzacji podejmowania decyzji; emancypacji grup społecznych; wzrostu efektywności decydowania; usprawnienia pracy administracji publicznej. Jednak istnieje także szereg negatywnych jej skutków ${ }^{29}$ - jak partykularyzm $^{30}$, klientelizm (np. zależność od jednostki urzędu, która jest inicjatorem BO) czy dominacja inicjatyw doraźnych. Dodatkowo - ponieważ funkcjonujace w Polsce regulacje prawne nie określaja, jaka jest moc wiążąca konsultacji społecznych - to decydenci, choć powinni brać ich rezultat pod uwagę, nie muszą uznawać go za ostateczny ${ }^{31}$. Jest tak zarówno w przypadku konsultacji obligatoryjnych, jak i fakultatywnych, chociaż prowadzone są prace, aby już na poziomie ustawy określić katalog spraw, których poddanie pod konsultacje jest obowiązkowe ${ }^{32}$.

${ }^{25}$ S. R. Arnstein, A ladder of citizen participation, „Journal of the American Institute of Planners" 4, 1969.

${ }^{26}$ W. Kębłowski, M. Van Criekingen, Participatory budgeting Polish-style. What kind of policy practice has travelled to Sopot, Poland?, w: N. Diaz (ed.), Hope for Democracy: 25 Years of Participatory Budgeting Worldwide, 2014, s. 369-377.

${ }^{27} \mathrm{~Np}$.http://www.katowice.eu/Konsultacje/Strony/Konsultacje-spo\%C5\%82eczne-dotycz\%C4\% 85ce-budowy-kompleksu-sportowego-przy-ul--Asnyka-w-Katowicach.aspx [dostęp: 25.01.2015].

${ }^{28} \mathrm{~J}$. Newig, O. Fritsch, More input - better output: does citizen involvement improve environmental governance, w: I. Blühdorn (ed.), In Search of Legitimacy. Policy Making in Europe and the Challenge of Complexity, Verlag Barbara Budrich, [b.m.] 2009, s. 205-224.

${ }^{29}$ B. Wampler, A guide to participatory budgeting, w: A. Shah (ed.), Participatory Budgeting, Washington 2007, s. 21-54.

${ }^{30}$ Por. przypadek zwycięskiego projektu w Łodzi dotyczącego realizacji budowy boisk sportowych na kwotę niemal $9 \mathrm{mln}$ zł, http://www.instytutobywatelski.pl/22225/lupa-instytutu/ruchy-miejskie-spojrzenie-z-dystansu [dostęp: 15.01.2015].

${ }^{31}$ Np. ustawa z 27 marca 2003 r. o planowaniu i zagospodarowaniu przestrzennym, Dz. U. 2003, Nr 80, poz. 717 ze zm.; ustawa z 3 października 2008 r. o udostępnianiu informacji o środowisku i jego ochronie, udziale społeczeństwa w ochronie środowiska oraz o ocenach oddziaływania na środowisko, Dz. U. 2008, Nr 199, poz. 1227 ze zm.; ustawa z 8 marca 1990 r. o samorządzie gminnym, Dz. U. 1990, Nr 16, poz. 95 ze zm.

${ }^{32}$ M. Banat, Konsultacje spoteczne $w$ samorzqdzie terytorialnym, „Samorząd Terytorialny” 24, 2014, nr 1-2, s. 13-25. 


\section{Budżety obywatelskie}

Zyskującym na popularności przykładem konsultacji społecznych w jednostkach samorządu terytorialnego stały się w ostatnich trzech latach budżety obywatelskie. Do stycznia 2014 r. 80 gmin skorzystało z tego, zastosowanego początkowo w Brazyliii ${ }^{33}$, sposobu konsultowania pewnej części budżetu gminy, przy czym w niektórych przypadkach była to już nie pierwsza, ale druga lub nawet trzecia edycja.

W Polsce standardy dla BO wyznaczył Sopot, który jako pierwszy - nie licząc specyficznego przypadku Płocka - skorzystał ze sprawdzonych w Ameryce Łacińskiej wzorów budżetowania partycypacyjnego ${ }^{34}$. Kontekst sopocki był jednak zupełnie odmienny od południowoamerykańskiego ${ }^{35}$, choćby dlatego, że Sopot to jedno z najbogatszych miast w Polsce, a projekty, na które głosowano w pierwszej edycji, nie były przedstawiane przez mieszkańców, lecz przez lokalna administrację ${ }^{36}$.

Niezależnie od zalet BO, podczas jego organizacji zdarzają się wypaczenia, zarówno po stronie władz ${ }^{37}$ (klientelizm, autopromocja w walce wyborczej), jak i po stronie obywateli (tworzenie organizacji parasolowych/konsorcjów dominujących w walce o środki z BO). Bardzo istotna jest też rola mediów, które zamiast na procesie współdecydowania ze wszystkimi jego rezultatami, skupiają się na „wynikach” (liczbie głosów) i „wygranych” (zwycięskich projektach i kwotach) ${ }^{38}-\mathrm{w}$ efekcie sztaby promocyjne BO promuja je głównie na zasadach ustalonych przez media. Takie tendencje można dostrzec w największych miastach Polski, np. w Warszawie, Poznaniu, Łodzi i Krakowie ${ }^{39}$. W gminach wiejskich (głównie - gdyż sporadycznie także w miastach ${ }^{40}$ ) funkcje podobne do BO spełniaja fundusze sołeckie, a na poziomie jednostek pomocniczych (w gminach miejskich) - systemy grantowe i fundusze, którymi dysponuja rady osiedli. Mechanizmy te jednak nie cieszą się tak dużym zainteresowaniem mediów i są mniej dyskutowane.

Należy podkreślić, że konsultacje same w sobie niosą szereg korzyści oprócz współdecydowania, mają służyć edukacji oraz komunikacji, tonując i weryfikując radykalne pomysły niektórych środowisk społecznych ${ }^{41}$, umoż-

${ }^{33}$ E. Ganuza, G. Baiocchi, The power of ambiguity: how participatory budgeting travels the globe, „Journal of Public Deliberation” 8(2), 2012.

${ }^{34}$ W. Kębłowski, M. Van Criekingen, op. cit.

${ }^{35}$ I. Bruce, Participatory democracy - the debate, w: idem (ed.), The Porto Alegre Alternative. Direct Democracy in Action, London 2004, s. 41.

${ }^{36}$ W. Kębłowski, M. Van Crekingen, op. cit.

${ }^{37}$ M. Milewicz, K. Podemski, Konsultacje czy manipulacje?, w: J. Erbel, P. Sadura (red.), Partycypacja. Przewodnik Krytyki Politycznej, Warszawa 2012, s. 180.

${ }^{38}$ P. Matczak, K. Mączka, M. Milewicz, E-partycypacja: zastosowania sondażu internetowego jako narzędzia partycypacyjnego, „Ruch Prawniczy, Ekonomiczny i Socjologiczny” 77, 2015, z. 1, s. 239-256.

${ }^{39}$ Por. np. W. Kębłowski, Budżet partycypacyjny. Ewaluacja, Instytut Obywatelski, Warszawa 2014 .

${ }^{40}$ Dostępny na: http://www.funduszesoleckie.pl/13,675,solectwa_i_fundusz_solecki_w_gminach_miejskich.html [dostęp: 12.02.2015].

${ }^{41}$ K. W. Frieske, Polowanie na jednorożca: demokratyczna administracja publiczna?, „Samorząd Terytorialny” 24, 2014, nr 1-2, s. 5-12. Zob. także: D. Olko, P. Sadura, 
liwiają poszczególnym grupom obywateli zrozumienie poglądów innych grup czy uchwycenie złożoności problemów wspólnoty, ale uświadamiają też, że niekiedy bezpieczniejszym rozwiązaniem może okazać się rezygnacja z własnej podmiotowości na rzecz wyspecjalizowanych administratorów. Na tym tle konsultacje społeczne niekoniecznie trzeba uznać za mechanizm demokracji bezpośredniej ${ }^{42}$ czy monitorującej ${ }^{43}$, która ma przywracać tzw. prawo do mia$\mathrm{sta}^{44}$, ale raczej za pewien bufor pomiędzy tymi dwoma rodzajami demokracji a demokracją pośrednią który może regulować napięcia społeczne.

Doświadczenia stosowania procesów partycypacyjnych w Polsce są ciagle jeszcze na etapie formowania i testowania, a istniejacce dane są niesystematyczne. To, że trudno więc w tak krótkiej perspektywie czasowej jednoznacznie ocenić działania propartycypacyjne w polskich samorządach, pokazują też dobitnie dyskusje pomiędzy naukowcami i praktykami ${ }^{45}$. Należy jednak podkreślić, że konsultacje społeczne to mechanizmem zarządzania gmina, który w zależności od tego, jak zostanie użyty, może przynieść zarówno skutki negatywne, jak i pozytywne dla całej społeczności lokalnej.

\section{JEDNOSTKI POMOCNICZE: MIĘDZY OBYWATELEM A WLADZĄ LOKALNĄ}

Reforma samorządowa upodmiotowiła gminy, a możliwość stworzenia jednostek niższego rzędu (dzielnic, osiedli i sołectw) wskazana została w unormowaniach ustawowych fakultatywnie. Brak prawnej podmiotowości rad osiedli/ dzielnic/sołectw stanowił konsekwencję rozstrzygnięć ustrojowych. Trzeba jednak pamiętać, że działające do 1990 r. jednostki pomocnicze - zwłaszcza w miastach - były traktowane z nieufnościa - nierzadko jako przejaw działania komunistycznego betonu ${ }^{46}$.

Sołectwa i rady osiedli nie mogą być traktowane jako formy samoorganizacji społecznej mieszkańców gminy, ponieważ stanowią przejaw dekoncentra-

Interwencja socjologiczna jako odpowiedź na kryzys miasta. Studium przypadku konsultacji w sprawie modernizacji ul. Kawęczyńskiej w Warszawie, „Studia Regionalne i Lokalne” 2014, nr 3, s. 87-104.

${ }^{42}$ M. Banat, op. cit.

${ }^{43}$ K. W. Frieske, op. cit.

${ }^{44}$ B. Lenkowski w artykule Ruchy miejskie - spojrzenie $z$ dystansu, stawia tezę, że problem z prawem do miasta nie tkwi w jego braku (reforma samorządowa zapewniła wszystkim obywatelom możliwość głosowania i kandydowania w transparentnych wyborach powszechnych), lecz w nieumiejętnym korzystaniu z niego, http://www.instytutobywatelski.pl/22225/lupa-instytutu/ ruchy-miejskie-spojrzenie-z-dystansu [dostęp: 15-01-2015].

${ }^{45}$ Np. R. Drozdowski, M. Frąckowiak, Bilans spotecznej wyobraźni. Komentarz socjologiczny do Poznańskiego Budżetu Obywatelskiego, „Ruch Prawniczy Ekonomiczny i Socjologiczny” 75, 2013, z. 4, s. 197-214; R. Grobelny, Dla kogo Poznański Budżet Obywatelski?, „Ruch Prawniczy Ekonomiczny i Socjologiczny” 76, 2014, z. 3, s. 315-319; G. Ganowicz, Uwagi po lekturze artykutu Bilans społecznej wyobraźni. Komentarz Socjologiczny do Poznańskiego Budżetu Obywatelskiego, „Ruch Prawniczy Ekonomiczny i Socjologiczny” 76, 2014, z. 3, s. 319-323.

${ }_{46}$ P. Swianiewicz et al., Btędne rondo marginalizacji? Jednostki pomocnicze samorzadu $w$ zarzqdzaniu dużymi miastami, Warszawa 2013; E. Łojko, Działacze samorzqdu mieszkańców-dysfunkcjonalny element osiedlowej samorzadności, „Przegląd Socjologiczny” 35, 1985. 
$\mathrm{cji}^{47}$. Jednocześnie jednak jednostki pomocnicze stanowić mogą formę organizacyjną administracji lokalnej najbliższą codziennym sprawom mieszkańców. Dotyczy to zwłaszcza gmin dużych (miejskich), w odniesieniu do których mówienie o wspólnocie mieszkańców może mieć jedynie metaforyczny sens, ponieważ bezpośrednie kontakty w ramach wielotysięcznych zbiorowości nie są możliwe.

W przypadku sołectw ustawa z 1990 r. niewiele zmieniła. Sołectwa sa instytucją społecznie zakorzenioną w życiu społeczności wiejskich. Ich możliwości działania były niewielkie, lecz stanowiły (i stanowia) one tradycyjne forum artykulacji lokalnych interesów. Działa ich w Polsce ok. 40 tys. W 2009 r. utworzono fundusz sołecki, którego celem jest zapewnienie minimum środków, którymi mogą dysponować sołectwa.

$\mathrm{Z}$ kolei jednostki pomocnicze $\mathrm{w}$ miastach pełnia zazwyczaj marginalna rolę w wykonywaniu zadań publicznych o charakterze lokalnym - ich prawne umocowanie i zakres kompetencji oraz zasoby nie pozwalają na więcej. Tworzenie ich po 1990 r. przebiegało w dwojaki sposób: w niektórych przypadkach rady gminy dzieliły miasto na dzielnice i przeprowadzały tam wybory do rad osiedli (lub dzielnic - stosowane są obydwie nazwy), w innych władze gminy oczekiwały na oddolne inicjatywy mieszkańców i ogłaszały wybory wówczas, gdy wolę posiadania rady zgłaszali mieszkańcy ${ }^{48}$.

Samo działanie rad osiedli ocenić można jako słabe - o ile na początku lat dziewięćdziesiątych rady działały siłą aktywistów (częściowo wywodzących się z komitetów obywatelskich i reprezentantów innych grup), o tyle z czasem zaczęły tracić swoją dynamikę ${ }^{49}$. W kilku miastach rady powstały, lecz następnie zaprzestały działalności. Około 2008 r. niektóre miasta rozpoczęły prace mające na celu reorganizację działania rad osiedli. Przyniosło to pewne uporządkowanie tych struktur, wzmocnienie ich roli i kompetencji ${ }^{50}$.

Tworzenie rad osiedli należy rozpatrywać w perspektywie zwiększania partycypacji mieszkańców oraz przekazywania zadań na poziom osiedli i sasiedztw w celu lepszego dopasowania usług do potrzeb. Choć można przedstawić szereg pragmatycznych i teoretycznych argumentów wskazujących na to, że tworzenie rad osiedli jest rozsądnym rozwiązaniem, doświadczenia są raczej negatywne. Rady osiedli de facto stanowią strukturę hybrydową (między administracją publiczną a organizacyjną reprezentacja mieszkańców). Pełnią jednak głównie funkcję przekaźnika informacji w dół - są wykorzystywane przez władze gmin do informowania i konsultowania decyzji, a tylko $\mathrm{w}$ niewielkim stopniu sa kanałem wpływu mieszkańców na władzę ${ }^{51}$. Z kolei samodzielność decyzyjna samych rad jest iluzoryczna, gdyż w większości przypadków ich budżety są bardzo małe - poniżej jednego procenta wydatków

${ }^{47}$ H. Izdebski, Jednostki pomocnicze gminy - między organami gminy a obywatelami jako podmiotem władzy lokalnej, „Samorząd Terytorialny” 11, 2001, nr 11.

${ }^{48}$ P. Matczak, Rady osiedli. W poszukiwaniu sensu lokalnego dziatania, Poznań 2008.

${ }^{49}$ Ibidem.

${ }^{50}$ P. Swianiewicz et al., op. cit.

${ }^{51}$ P. Matczak, M. Kotnarowski, Jednostki pomocnicze samorzqdu: między obywatelem a wła$d z a$, w: A. Olech (red.), Dyktat czy uczestnictwo? Diagnoza partycypacji publicznej $w$ Polsce, Warszawa 2012, s. 211-233. 
budżetowych gminy. Słabość sprawcza rad osiedli łączy się z brakiem społecznego zakotwiczenia. W wyborach do rad bierze najczęściej udział kilka procent mieszkańców, rzadko przekraczając $10 \%$. Mieszkańcy nie zawsze są też świadomi istnienia $\mathrm{rad}^{52}$. Rozwiązaniem, które zwiększyłoby zainteresowanie mieszkańców działaniem rad i same rady uczyniłoby realną reprezentacją lokalnych potrzeb, jest radykalna decentralizacja ${ }^{53}$, ale takie rozwiązanie nie zostało dotąd sprawdzone w krajach europejskich.

O ile zatem sołectwa pełnia pewną rolę i działaja, bazując na sile tradycji oraz na naturalnej więzi stosunkowo spójnych społeczności ${ }^{54}$, o tyle w przypadku rad osiedli w miastach mamy częściej do czynienia z ułomnym funkcjonowaniem. Można wskazać uzasadnienia silnej roli rad osiedli, lecz obecna sytuacja jest patowa: rady maja małe kompetencje, mieszkańcy zaś nie interesują się nimi. Przekazanie większych kompetencji mogłoby przełamać impas, lecz wola władz miejskich jest $\mathrm{w}$ tym zakresie mała. $Z$ punktu widzenia władz bardziej atrakcyjne, ponieważ budzi zainteresowanie mediów i dyskusje, sa $\mathrm{np}$. wspominane już budżety obywatelskie.

\section{RUCHY MIEJSKIE JAKO PAPIEREK LAKMUSOWY EWOLUCJI SAMORZĄDU TERYTORIALNEGO?}

Zjawisko ruchów miejskich na tle procesu odbudowy samorządności terytorialnej ostatnich 25 lat można analizować w dwóch ujęciach: przedmiotowym i podmiotowym. W pierwszym - polityczny aktor: gmina, powiat, województwo „indukują" dynamikę społeczna, realizując zadania z zakresu edukacji, albo politykę przestrzenna, albo wspierają działalność inwestycyjna. W ujęciu podmiotowym ruch społeczny stanowi intencjonalną reakcję na przekształcenia ${ }^{55}$, w ramach których samorząd terytorialny i wspólnota lokalna potraktowane sa jako punkt odniesienia. W tym sensie podmiotowo pojmowany ruch społeczny znajduje się w samym centrum uogólnionego procesu społecznego nie tylko demokratyzacji (przebiegającej w formule transformacji ustrojowej z góry na dół), lecz także: deregulacji, reskalowania (ang. rescaling) czy stosowania zasady pomocniczości (ang. subsidiarisation) ${ }^{56}$. Na poziomie teorii ruchy miejskie można również łączyć z tzw. zwrotem przestrzennym (ang. spatial turn).

${ }^{52}$ M. Lackowska, Czy mieszkańcy wielkich miast potrzebuja jednostek pomocniczych, „Samorząd Terytorialny" 24, 2014, nr 1-2, s. 72-87.

53 P. Swianiewicz, Jednostki pomocnicze w dużych miastach: błędne koło marginalizacji, czy ślepa uliczka, „Samorząd Terytorialny” 24, 2014, nr 1-2, s. 55-71.

${ }_{54}$ P. Matczak, Kiedy dobrobyt zależy od wspótpracy... Dewastacja $i$ odbudowa dóbr wspólnych, w: A. Sakson, P. Węgierkiewicz (red.), Samorzqd pomocniczy jako czynnik pobudzajacy spoteczeństwo obywatelskie na wsi, Konin-Warszawa-Poznań 2010.

55 Por. N. Smelser, Theory of Collective Behavior, New York 1965; A. Touraine, The Voice and the Eye: An Analysis of Social Movements, Cambridge 1981; P. Sztompka, Socjologia. Analiza społeczeństwa, Kraków 2012.

56 Por. Y. Kazepov, The subsidiarisation of social policies: actors, processes and implication, „European Societies” 10(2), 2008; K. Pobłocki, Skala jako obiekt badań antropologicznych, w: J. Schmidt (red.), Regiony etnografii, Poznań 2013. 
W jego ramach refleksja nad życiem wspólnot (głównie miejskich) zostaje poszerzona o wątki urbanistyczne i zwraca się uwagę na miasto jako strukturę przestrzenno-społeczna, która jest zarówno wehikułem rozwoju, jak i polem społecznej konkurencji-konfliktu o zasoby. W podobny sposób pojmowane ruchy miejskie mają w Polsce stosunkowo krótką historię, sięgają one do początku pierwszego dziesięciolecia nowego millenium, kiedy to zaczęto wspominać o kryzysie samorządności. Jest symptomatyczne, że punktem zwrotnym były protesty wobec zmian przestrzennych proponowanych przez władze samorządowe, a w efekcie wokół działań nielicznej grupy osób ${ }^{57}$ zaczęło formować się środowisko działaczy społecznych, stając się zalążkiem struktur stowarzyszeniowych oraz polem rekrutacji nowych elit.

Nie wszystkie przejawy aktywności obywatelskiej można potraktować jako ruchy miejskie, wszystkie jednak odwołują się i odwoływały do tożsamości typu terytorialnego, która rodziła się, gdy demokratyczny wybór reprezentantów okazywał się dla mieszkańców/obywateli niewystarczający. Ambicje tego nowego środowiska szybko wykroczyły jednak poza kontekst społeczności lokalnej - przykładem może być zorganizowany w 2011 r. I Kongres Ruchów Miejskich, który zgromadził kilkadziesiąt organizacji, w tym zarówno reformistyczne ruchy postulujace intensyfikację polityki inwestycyjnej (często we współpracy z władzami miejskimi), środowiska późniejszej partii Zielonych, czy tzw. Ruchu Palikota, jak i pierwotny trzon organizacyjny oparty na działaczach, którzy kilka lat wcześniej skutecznie oprotestowywali politykę inwestycyjną miast. Kongres nie był wydarzeniem jednostkowym, kolejne obyły się w Łodzi w 2012 i Białymstoku w 2013 r.

Analizując ostatni z kongresów, warto wskazać na trzy wypracowane dokumenty: krytyczny list otwarty dotyczący ustawy „Mieszkanie dla Młodych” (forsującej budownictwo prywatne w opozycji np. do działań rewitalizacyjnych); stanowisko w sprawie podziału środków na ochronę zabytków (preferujące duże ośrodki miejskie) oraz opinię wspierajacca referenda lokalne jako narzędzie zmiany władz miejskich, gdy ich polityka jest powszechnie krytykowana ${ }^{58}$. Ogólnopolska aktywność zaowocowała zaangażowaniem się części działaczy lokalnych w opracowywanie Założeń Krajowej Polityki Miejskiej ${ }^{59}$.

W konsolidującym się środowisku aktywistów miejskich pozostała otwartą kwestia, czy ruchy miejskie powinny występować podmiotowo, np. w wyborach samorządowych, i czy nie jest to przekroczenie bariery oddzielającej działaczy społecznych od „partyjnej” polityki lokalnej. Spora część ruchów odpowiedziała, że „powinny”, i wzięła udział w wyborach, powołując do życia kolejny podmiot: „Porozumienie Ruchów Miejskich”, który stanowi nowy ele-

${ }^{57}$ Których polityczny rodowód związany był jeszcze z komitetami obywatelskimi z przełomu lat osiemdziesiątych i dziewięćdziesiątych XX w. oraz tzw. Ruchem Zielonych.

${ }^{58}$ Opis III Kongresu i odnośniki do wskazanych dokumentów można znaleźć w dokumencie autorstwa Joanny Erbel (eadem, Po III Kongresie Ruchów Miejskich, „Krytyka Polityczna. Dziennik Opinii”, http://www.krytykapolityczna.pl/en/artykuly/miasto/20131021/erbel-po-iii-kongresie-ruchow-miejskich; dostęp: 12.02.2015).

${ }_{59}$ Tekst dokumentu dostępny jest na stronie Ministerstwa Infrastruktury i Rozwoju: https:// www.mir.gov.pl/aktualnosci/polityka_rozwoju/Documents/Zalozenia_KPM_20_lipca_po_uwagach_MMN.pdf [dostęp: 20.05.2015]. 
ment na mapie polskiej samoorganizacji ${ }^{60}$. Jest widoczne, że w przypadku tych samorządów, w których ruchy miejskie były w stanie wystapić podmiotowo, wprowadziły one do rad swoich przedstawicieli, a w kilku przypadkach były w stanie skutecznie zaproponować kandydata na wiceprezydenta bądź wręcz przejąć władzę wykonawczą w mieście (np. w Gorzowie). W kontekście kondycji polskiej samorządności ruchy miejskie wydają się swoistym odrodzeniem idei demokracji na poziomie lokalnym i powrotem do samorządu aktywistów, a nie administratorów.

\section{SAMORZĄD WOJEWÓDZKI A TOŻSAMOŚĆ REGIONALNA}

Regionalizacja była dyskutowana w Polsce od początku lat dziewięćdziesiątych $^{61}$, jednakże dla kondycji regionalizmu w Polsce kluczowy był tzw. drugi etap reformy administracyjnej, wdrożonej z dniem 1 stycznia 1999 r., tworzącej m.in. jednostki struktury administracyjno-terytorialnej szczebla regionalnego oraz nadającej im status jednostek samorządu terytorialnego. Pojęcie regionalizmu rozumiane jest jako całokształt zjawisk (społeczno-kulturowych, gospodarczych, politycznych) wypływających ze związków, jakie tworzą się między obszarem spełniającym kryteria pozwalajacce uznać go za region a jego mieszkańcami i wewnattrz tworzonej przez nich zbiorowości - ciagle stanowi przedmiot sporu. Poniżej uwaga skupi się na dwóch (spośród trzech) wymiarach składajacych się na tak rozumiany regionalizm: społeczno-kulturowym (regionalizacja a tożsamość regionalna) oraz politycznym (regionalizacja a udział/reprezentacja zbiorowości regionalnej w prowadzonej polityce).

Odpowiedź na pytanie o znaczenie podziału administracyjnego na regiony dla polskiego regionalizmu (czy też polskich regionalizmów) wymaga uwzględnienia w rozważaniach dwóch etapów czasowych: 1) etapu dochodzenia do reformy i kształtowania jej formuły (toczona od początku lat dziewięćdziesiątych z aktywnym udziałem przedstawicieli środowisk regionalistycznych); 2) etapu realizacji oraz skutków wprowadzonych rozwiąań. Etap pierwszy - w uproszczeniu - pozwalał oczekiwać, że reforma przełoży się na wzmocnienie regionalizmów. Etap drugi - skłania do wniosku, że wskazane wcześniej oczekiwania nie zyskały potwierdzenia w rzeczywistości, a przynajmniej że dostrzegalna jest polaryzacja jej efektów (z wyraźną odmiennością sytuacji Górnego Śląska).

Można zatem postawić tezę, że przeprowadzona w Polsce reforma ustanawiająca nowe granice regionów (wbrew intencjom jej twórców) przyczyniła się do spadku znaczenia regionalizmu i osłabienia jego kondycji. Wskazać można trzy zasadnicze przesłanki tego stanu:

\footnotetext{
${ }^{60}$ Jest to nowy element po poziomej konsolidacji samorządów jeszcze w latach dziewięćdziesiątych XX w. (por. choćby Związek Miast Polskich, Związek Gmin Wiejskich itd.).

${ }^{61}$ G. Gorzelak, B. Jałowiecki (red.), Czy Polska będzie państwem regionalnym?, Warszawa 1993.
} 
- Spadek popularności oraz znaczenia koncepcji Europy Regionów jako rozwiązania odgrywającego ważną rolę dla dalszego rozwoju procesów integracji europejskiej. Jednocześnie nastapiło wzmocnienie pozycji władz centralnych, m.in. w wyniku globalnego kryzysu ekonomicznego. Można zaobserwować przejawy procesów dezintegracyjnych w państwach europejskich, w których reformy regionalizacyjne zostały wcześniej przeprowadzone (Hiszpania, Belgia). Pokazało to, że regionalizm może przynieść napięcia.

- Specyfika wdrożonych w Polsce rozwiązań legislacyjnych określajacych status samorządów regionalnych okazała się odległa od rozwiąań bliskich regionalnej autonomii. Nie zrealizowano postulatów stanowiacych w początku lat dziewięćdziesiątych siłę napędzającą rozwój polskich regionalizmów, przynajmniej w niektórych regionach. Zapewne pod wpływem obaw dezintegracji krajowe elity i ośrodki władzy przyjęły ostrożną politykę wobec ewentualnego poszerzania zakresu samodzielności jednostek terytorialnych. Doszło też do upartyjnienia struktur wojewódzkich władz samorządowych (m.in. jako rezultat przyjętych zapisów ordynacji wyborczej) ${ }^{62}$.

- W pewnym zakresie przeszacowano wyjściowy potencjał polskich regionalizmów. Choć dały się stwierdzić tożsamości regionalne ${ }^{63}$, to ich potencjał polityczny okazał się mały. Nie wytworzyła się również identyfikacja mieszkańców ze strukturami regionalnych samorządów. Władze wojewódzkie nie podjęły też działań zorientowanych na integrację regionów oraz ich mieszkańców i przyjęły rolę „,szafarzy europejskich darów”64. Co więcej, pojawiły się narastające napięcia pomiędzy regionalnym centrum a peryferiami, ujawniające się w społecznych odczuciach, zwłaszcza wśród mieszkańców miast, które utraciły w wyniku reformy status wojewódzkich stolic.

Sformułowanie jednoznacznej oceny ukształtowanej sytuacji nie jest jednak łatwe. Zależy ona bowiem od priorytetów stanowiących jej kryteria. Jeśli oceniać reformę regionalizacyjną np. przez pryzmat osłabienia ewentualnych tendencji separatystycznych, przy jednoczesnym poszerzeniu zakresu samorządności, można uznać ją za efektywną. Jeśli jednak wiązać z nią oczekiwane pobudzenie potencjału aktywności zbiorowości regionalnych czy wzmocnienie regionalnych tożsamości, to ocena będzie krytyczna. Napływ środków z Unii Europejskiej zarządzanych przez samorządy wojewódzkie w małym stopniu wykorzystuje potencjał regionalnych tożsamości i go nie wzmacnia. Zamiast tego obserwować można koncentrację na redystrybucji środków, w znacznym stopniu naznaczonej logiką politycznego konfliktu skutkującego klientelizmem połączonym ze skłonnością do spektakularnego inwestowania (często w oderwaniu od realnych potrzeb) ${ }^{65}$. Przykładem tego stanu rzeczy może być wybudowana w ciagu ostatnich lat siatka lotnisk, z których kilka ma problem z utrzymaniem połączeń.

${ }^{62}$ B. Gąciarz, Instytucjonalizacja samorzadności, Warszawa 2004.

63 J. Bartkowski, Tradycje i polityka, Warszawa 2003.

${ }^{64}$ P. Swianiewicz et al., Szafarze darów europejskich: kapitał społeczny a realizacja polityki regionalnej w polskich województwach, Warszawa 2008.

${ }_{65}$ P. Swianiewicz et al., Niestrategiczne zarzadzanie rozwojem, Warszawa 2010; T. G. Grosse, Jak $w$ Polsce realizujemy politykę regionalna?., Analiza Instytutu Sobieskiego, nr 72, Warszawa 2014. 


\section{PODSUMOWANIE I WNIOSKI}

Samorząd terytorialny w Polsce zmienił się znacznie od $1990 \mathrm{r}$. Obraz radnych z 1990 r., którzy nie uczestnicząc wcześniej w strukturach władzy, na pierwszych sesjach uczyli się głosować, został zastapiony przez profesjonalnie prowadzone kampanie wyborcze, przeprowadzanie skomplikowanych przetargów i wyrafinowanych czasami operacji politycznych dla osiagnięcie pewnych decyzji. Znacząco zmieniły się też obraz polskich miast i wsi oraz poziom infrastruktury komunalnej. Osiagnięcia samorządności w tym zakresie sa niewatpliwe. W artykule na wybranych przykładach przedstawiono analizę w obszarze aktywizacji społecznej, która miała być - w zamierzeniach twórców reform - jednym z efektów przywrócenia samorządu terytorialnego w Polsce w 1990 r. Zarysowany obraz nie jest jednoznaczny. Jeśli uznać, że celem reformy samorządowej było praktyczne zrealizowanie idei pomocniczości, to cel ten został osiagnięty w tym sensie, że Polska dysponuje efektywna administracją realizujacca zadania własne od poziomu gminy po województwo. Partycypacja obywateli w zarządzaniu regionami realizuje się regularnie przez wybory, sektor organizacji pozarządowych rozwiną się i organizacje te współpracuja z jednostkami samorządu terytorialnego, jednostki pomocnicze działaja (choć sołectwa lepiej niż rady osiedli), funkcjonują rozmaite metody partycypacji obywateli w procesach decyzyjnych realizowanych przez administracje samorządowe, grupy obywateli maja możliwość wywierania wpływu na działania samorządów, wspólnoty regionalne mają możliwość kultywowania swej tożsamości.

Jednak bliższe przyjrzenie się „społecznemu komponentowi samorządności” skłania do ostrożności w ogłaszaniu sukcesu. W przypadku jednostek pomocniczych dobrze działają najstarsze z nich, tj. sołectwa. Z kolei województwa są stosunkowo upolitycznionym szczeblem administracji.

Niemniej względna słabość „drugiej nogi” reformy samorządowej, tj. organizacji pozarządowych i ukierunkowanie na zwiększanie niewyborczego zakresu partycypacji mieszkańców, dała - z jednej strony - efekt w postaci wyraźnego wzrostu działań partycypacyjnych - konsultacji społecznych w rodzaju budżetu obywatelskiego. Pozwalaja one mieszkańcom na faktyczne współdecydowanie, a przynajmniej - niewyborczą dyskusję z władzami lokalnymi, choć odbywa się ona jako aktywność animowana przez owe władze. Z drugiej strony równie wyraźny jest bardziej oddolny i burzliwy nurt ruchów miejskich, które stoją wobec wyboru między partycypacją wyborczą i niewyborczą.

Trudno stwierdzić, czy konsultacje społeczne z jednej strony, a ruchy miejskie z drugiej zyskuja na znaczeniu kosztem organizacji pozarządowych i dzięki słabości tych organizacji. Niewątpliwie ani procesy konsultacji społecznych, ani ruchy miejskie nie są w stanie w pełni zastapić stabilnych partnerów samorząqów w realizowaniu ich zadań, choć uzupełniają je żądaniami uwzględniania dążeń i oczekiwań mieszkańców. Nie są to relacje wolne od wielu negatywnych zjawisk (jak populizm bądź klientelizm). Z kolei za słabość organizacji pozarządowych w relacjach z samorządem częściowo odpowiadaja postawy przedstawicieli administracji samorządowej. 
Niewątpliwy sukces polskiego samorządu, który zmienił Polskę, nie przełożył się na sukces polskiej samorządności, rozumianej jako sfera harmonijnej współpracy wybieralnych władz lokalnych odpowiedzialnych wobec aktywnych społeczności. Struktury samorządu zdominowały życie lokalne, w wielu przypadkach urzędy stanowią największego pracodawcę (co powoduje negatywne skutki ekonomiczne i społeczne), nadzieje z początku lat dziewięćdziesiątych związane z obywatelską rolą prasy lokalnej okazały się iluzja, sektor pozarządowy jest w bardzo poważnym stopniu uzależniony od władz samorządowych. Porażka samorządności w sensie społecznym jest więc w pewnym sensie dzieckiem sukcesu reformy samorządowej.

\author{
dr hab. Piotr Matczak \\ Uniwersytet im. Adama Mickiewicza w Poznaniu \\ matczak@amu.edu.pl \\ dr Agnieszka Jeran \\ Uniwersytet im. Adama Mickiewicza w Poznaniu \\ jeran@amu.edu.pl \\ mgr Krzysztof Maczka \\ Uniwersytet im. Adama Mickiewicza w Poznaniu \\ krzysztof.maczka@amu.edu.pl \\ dr Marek Nowak \\ Uniwersytet im. Adama Mickiewicza w Poznaniu \\ marek.nowak@amu.edu.pl \\ dr Pawet Śliwa \\ Uniwersytet im. Adama Mickiewicza w Poznaniu \\ p.sliwa@amu.edu.pl
}

\title{
SOCIAL ACTIVATION OF LOCAL COMMUNITIES IN POLAND FROM THE PERSPECTIVE OF 25 YEARS OF SELF-GOVERNMENT
}

\author{
Sum mary
}

The revival of local government in 1990 constituted a fundamental change in the Polish political regime. However, on the twenty-fifth anniversary of this event the picture of local government in Poland is still unclear. The article offers answers to questions about how the expectations related to the revitalisation of local communities through the revival of local government have been met and about the scope of the idea of subsidiarity implementation. The following areas of social life are analysed: (i) the activity of what are known as third sector organisations and their cooperation with local government (horizontal subsidiarity); (ii) the use of procedures and techniques of participation by local government; (iii) the functioning of local government auxiliary units (district councils and village councils - vertical subsidiarity); (iv) activities of urban social movements and initiatives; (v) regionalism. Considering the practical implementation of the idea of subsidiarity as the main purpose of the local government reform, the objective has been achieved. However, the unquestionable success of the Polish self-government which have changed Poland for the better does not entail the revival of Polish local communities. The harmonious cooperation of elected local authorities accountable to an active community is still missing. Local government structures have dominated local life, being in many places the largest employer, with all negative consequences of this in terms of both economic and social life. In this sense, it can be argued that a partial failure of self-government is a side effect of the success of the self-government reform. 
